\title{
Theranostic Au Cubic Nano-aggregates as Potential Photoacoustic Contrast and Photothermal Therapeutic Agents
}

\author{
Juan $\mathrm{Hu}^{1}$, Xianglong Zhu' ${ }^{1}$, Hui Li ${ }^{2}$, Zhenghuan Zhao', Xiaoqin $\mathrm{Chi}^{2}$, Guoming Huang ${ }^{1}$, Dengtong Huang ${ }^{1}$, \\ Gang Liu ${ }^{3}$, Xiaomin Wang2, and Jinhao Gao ${ }^{1,3}$ \\ 1. State Key Laboratory of Physical Chemistry of Solid Surfaces, The MOE Key Laboratory of Spectrochemical Analysis \& Instrumentation, \\ The Key Laboratory for Chemical Biology of Fujian Province, and Department of Chemical Biology, College of Chemistry and Chemical \\ Engineering, Xiamen University, Xiamen 361005, China. \\ 2. Fujian Provincial Key Laboratory of Chronic Liver Disease and Hepatocellular Carcinoma, Zhongshan Hospital, Xiamen University, \\ Xiamen 361004, China. \\ 3. Center for Molecular Imaging and Translational Medicine, School of Public Health, Xiamen University, Xiamen 361102, China.
}

\begin{abstract}
$\square$ Corresponding author: jhgao@xmu.edu.cn.
() Ivyspring International Publisher. This is an open-access article distributed under the terms of the Creative Commons License (http://creativecommons.org/
\end{abstract} licenses/by-nc-nd/3.0/). Reproduction is permitted for personal, noncommercial use, provided that the article is in whole, unmodified, and properly cited.

Received: 2013.1I.21; Accepted: 2014.01.06; Published: 2014.02.25

\begin{abstract}
Multifunctional nanostructures combining diagnosis and therapy modalities into one entity have drawn much attention in the biomedical applications. Herein, we report a simple and cost-effective method to synthesize a novel cubic Au nano-aggregates structure with edge-length of $80 \mathrm{~nm}$ (Au-80 CNAs), which display strong near-infrared (NIR) absorption, excellent water-solubility, good photothermal stability, and high biocompatibility. Under $808 \mathrm{~nm}$ laser irradiation for $5 \mathrm{~min}$, the temperature of the solution containing Au- $80 \mathrm{CNAs}(100 \mu \mathrm{g} / \mathrm{mL})$ increased by $\sim 38^{\circ} \mathrm{C}$. The in vitro and in vivo studies demonstrated that Au-80 CNAs could act as both photothermal therapeutic (PTT) agents and photoacoustic imaging (PAI) contrast agents, indicating that the only one nano-entity of Au-80 CNAs shows great potentials for theranostic applications. Moreover, this facile and cost-effective synthetic method provides a new strategy to prepare stable Au nanomaterials with excellent optical properties for biomedical applications.
\end{abstract}

Key words: Au cubic nano-aggregates, near-infrared absorption, theranostics, photothermal therapy, photoacoustic imaging.

\section{Introduction}

Metallic nanostructures (e.g., $\mathrm{Au}, \mathrm{Cu}$, and $\mathrm{Pd}$ ) have attracted explosive attentions in the fields of catalysis [1, 2], photonics [3], and especially biomedical applications over the past decades, which trigger numerous research interests in evaluating their biological sensing [4], drug delivery [5, 6], cancer therapy $[7,8]$, and molecular imaging abilities $[9,10]$. For example, photoacoustic imaging (PAI) is a recently developed technique based on the excellent optical properties of metallic nanomaterials, which combines the advantages of high selectivity of optical imaging and high spatial resolution of ultrasonic imaging [11, 12]. Moreover, the strong near-infrared (NIR) light absorption characteristics of metallic nanomaterials also promise an great potential application in photothermal therapy (PTT) with high selectivity, excellent efficacy, and minimal invasiveness compared to traditional clinical therapeutic methods (e.g., chemotherapy and radiotherapy) [13, 14]. Therefore, the possibility to combine diagnosis modalities and 
therapy applications into metallic nanomaterials of one entity, also named as theranostics, may offer great advantages in disease management and prognosis [15-19].

Among the various kinds of available metallic nanostructures, Au nanomaterials are one of the most extensively studied platforms owing to their excellent tunable optical properties by well-controlled morphologies [20-22]. Au nanomaterials with various shapes (e.g., shell, rod, star, and cage) have been exploited as exogenous PTT agents [23-27] or PAI contrast agents [28-31], which are alternatively promising strategies to efficiently diagnose and treat cancers on account of their low photobleaching, tunable surface plasmon resonance (SPR) properties, strong absorption in NIR region, and high photothermal energy conversion efficiency [32-34]. Especially, gold nanoshells, (also called Auroshell, which is $155 \mathrm{~nm}$ in diameter with a surface coating of polyethylene glycol 5000) have been employed in the early clinic studies for the photothermal treatment of head, neck and prostate cancers [35]. However, the existing shortcomings on the fabrication process and the intrinsic properties largely limit the broad applications of Au-based nanomaterials. In the case of gold nanoshells, there is a potential concern for the reason that the large shells are difficult to excrete from the body for extended periods of time [35]. The use of cetyltrimethylammonium bromide (CTAB) in the synthesis of $\mathrm{Au}$ nanorods results in additional time and labor-consuming in the further purification and modification [36]. In addition, the Au nanorods have weak stability under NIR irradiation since they are prone to melt and lose their efficiency $[37,38]$. It is an uneconomical method for the synthesis of gold nanocages when using noble metal silver as consumables [39]. It is thus highly desirable to develop a facile and cost-effective strategy to fabricate photo-stable $\mathrm{Au}$ nanostructures with strong absorption in NIR region for PAI and PTT applications.

Herein, we showed a simple and cost-effective method to synthesize different sized $\mathrm{Au}$ cubic nano-aggregates (Au CNAs) with hollow inner space using $\mathrm{Cu}_{2} \mathrm{O}$ nanocubes as templates. The $\mathrm{Au}$ CNAs with average sizes of $80 \mathrm{~nm}$ (Au- 80 CNAs) exhibited excellent water solubility without further modification because of the surface coating of amine-terminated monomethoxy polyethylene glycol (mPEG-NH $)_{2}$ during the formation. More importantly, the as-prepared Au- 80 CNAs showed tunable absorption properties in the NIR region and excellent photothermal performance. The in vitro and in vivo studies demonstrated that Au- 80 CNAs can act as both PTT agents for cancer therapy and PAI contrast agents for tumor imaging (Scheme 1/Figure A). These results may provide an excellent candidate of Au-based nanomaterials for efficient theranostic applications and further clinical translations.
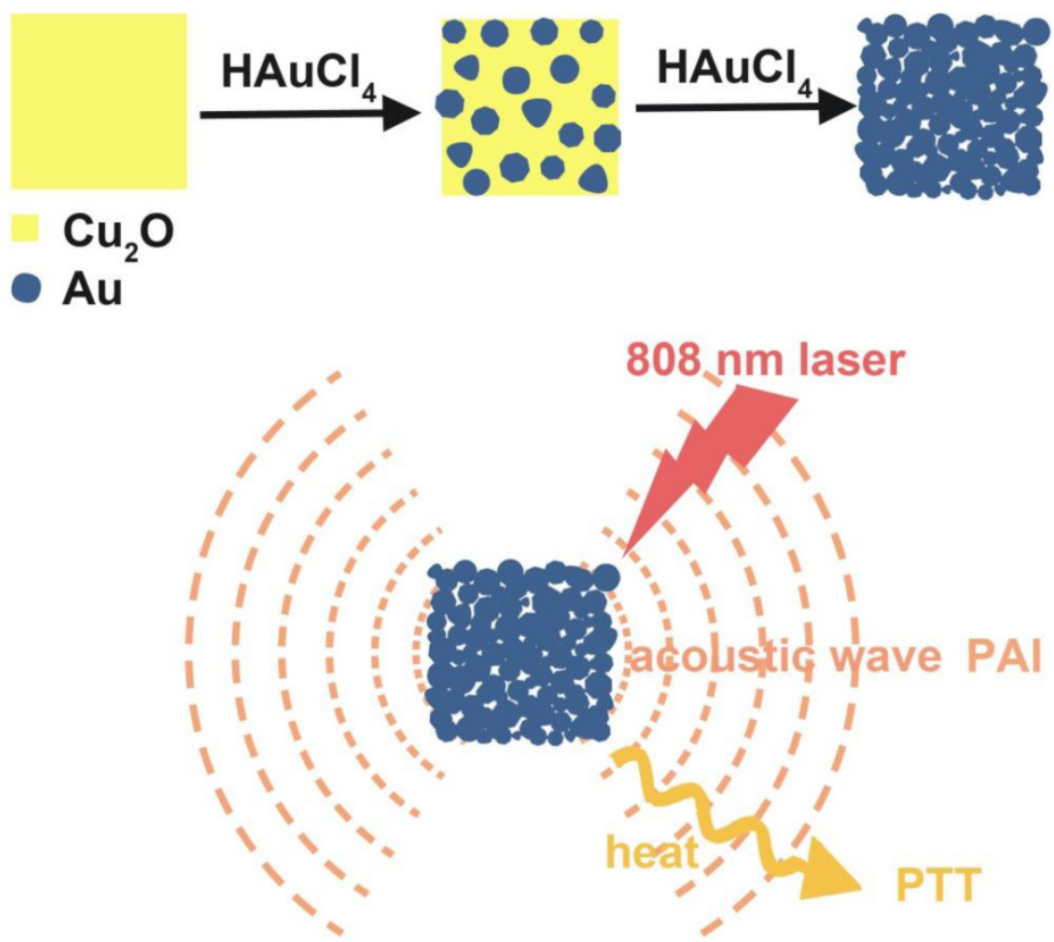

Figure A. (Scheme I) Schematic illustration of the synthesis of Au-80 CNAs using $\mathrm{Cu}_{2} \mathrm{O}$ nanocubes as templates and the potential applications of Au- $80 \mathrm{CNAs}$ in photoacoustic imaging (PAI) and photothermal therapy (PTT). 


\section{Experimental Sections}

\section{Chemicals and materials}

Hydrogen tetrachloroaurate (III) trihydrate (99.99\%) ( $\left.\mathrm{HAuCl}_{4} .3 \mathrm{H}_{2} \mathrm{O}\right)$ was purchased from Alfa Aesar. Amino-methoxyl polyethyleneglycol (mPEG$\mathrm{NH}_{2}, \mathrm{MW} 750$ ) was purchased from Biomatrik Inc. Ascorbic acid (AA), sodium hydroxide $(\mathrm{NaOH})$, copper (II) sulfate pentahydrate $\left(\mathrm{CuSO}_{4} .5 \mathrm{H}_{2} \mathrm{O}\right)$ and other reagents were purchased from Sinopharm Chemical Reagent Co., Ltd. All chemicals were used as received without further purification. Ultrapure water (18.2 $\mathrm{M} \Omega \cdot \mathrm{cm}$ ) was used for all solution preparations.

\section{Characterization}

Scanning electron microscopy (SEM) images and elemental analysis were obtained using a HITACHI S-4800 scanning electron microscope equipped with energy dispersive X-ray spectroscopy. Transmission electron microscopy (TEM) and selected area electronic diffraction (SAED) images were acquired on JEM-2100 microscope at an accelerating voltage of 200 $\mathrm{kV}$. X-ray diffraction (XRD) patterns were collected using a Rigaku Ultima IV X-ray diffractometer with $\mathrm{Cu} \mathrm{Ka}$ radiation. The Absorption spectra were recorded by using a Varian Cary 5000 UV-vis-NIR spectrophotometer with a $1.0 \mathrm{~cm}$ optical path length quartz cuvette. The element analysis of $\mathrm{Au}$ and $\mathrm{Cu}$ was also carried out by inductively coupled plasma atomic emission spectroscopy (ICP-AES). Photothermal assay was induced by $808 \mathrm{~nm}$ laser from Hi-Tech Optoelectronics Co., Ltd. Fluorescence microscope images were obtained using Axio Observer. The tumor thermographs and temperature were recorded by an infrared camera (HM-300, Guangzhou SAT Infrared Technology Co., Ltd., China). The in vivo photoacoustic imaging experiment was carried on the Endra Nexus 128 Small Animal Photoacoustic Imaging System.

\section{Synthesis of $\mathrm{Cu}_{2} \mathrm{O}$ nanoparticles with controllable sizes}

The $\mathrm{Cu}_{2} \mathrm{O}$ nanoparticles were synthesized by modifying the protocol previously reported [40]. In a typical procedure, $\mathrm{CuSO}_{4}$ aqueous solution $(0.02 \mathrm{M}, 2$ $\mathrm{mL})$ and $\mathrm{mPEG}-\mathrm{NH}_{2}(\mathrm{MW}=750,0.05 \mathrm{M})$ were mixed in a round bottom flask with ultrapure water under vigorous stirring at room temperature. Subsequently, $\mathrm{NaOH}(0.5 \mathrm{M}, 3 \mathrm{~mL})$ and AA $(0.1 \mathrm{M}, 1 \mathrm{~mL})$ were mixed in a separate vessel with ultrapure water. The $\mathrm{NaOH}$ and AA mixture solution was quickly added to the round bottom flask. The reaction was allowed to perform at room temperature for 5 min under vigorous stirring. By varying the amount of $\mathrm{mPEG}-\mathrm{NH}_{2}$, the reaction solution turned from colorless to yellow or orange and $\mathrm{Cu}_{2} \mathrm{O}$ of different sizes could be acquired (Supplementary Material: Table S1). Then the reaction was quenched by adding $40 \mathrm{~mL}$ of ethanol and centrifuged at $6000 \mathrm{rpm}$ for $7 \mathrm{~min}$. After the top solution was decanted, the precipitate was washed with the mixture of $\mathrm{H}_{2} \mathrm{O}$ and ethanol (1:3) for four times to remove the unreacted chemicals and excess $\mathrm{mPEG}-\mathrm{NH}_{2}$. The nanoparticles were redispersed in 5 $\mathrm{mL}$ of ultrapure water. We synthesized $70 \mathrm{~nm} \mathrm{Cu}_{2} \mathrm{O}$ nanocubes by fixing the molar ratio of $\mathrm{CuSO}_{4}$ to mPEG-NH ${ }_{2}$ at 16:1.

\section{Synthesis of Au cubic nano-aggregates (Au CNAs)}

The freshly synthesized $\mathrm{Cu}_{2} \mathrm{O}$ nanocubes were immediately used for the preparation of $\mathrm{Au}$ CNAs. Briefly, $1 \mathrm{~mL}$ of the as-prepared $\mathrm{Cu}_{2} \mathrm{O}$ suspension was added to $10 \mathrm{~mL}$ of water and sonicated for $5 \mathrm{~min}$. Then we added the mixture of $\mathrm{HAuCl}_{4}(0.4 \mathrm{mM})$ and $\mathrm{HCl}(0.8 \mathrm{mM})$ drop by drop under sonication and ice-water bath. The solution gradually changed from yellow or orange to greenish yellow, then to green and finally produced a blue colloid. The Au CNAs were separated by centrifugation, washed with distilled water and ethanol, and redispersed in water for further use. Au CNAs with different sizes could be obtained by using different sized $\mathrm{Cu}_{2} \mathrm{O}$ nanocubes as templates. By changing the molar ratio of $\mathrm{HAuCl}_{4} / \mathrm{Cu}_{2} \mathrm{O}$ nanocubes from 0:12 to 8:12, we could easily tune the absorption peaks from visible region to near infrared region. Au-80 CNAs (Au CNAs with edge-length of $80 \mathrm{~nm}$ ) with the maximum absorption at $\sim 805 \mathrm{~nm}$ were chosen for the following experiments.

\section{Photothermal performance in solution}

The Au- 80 CNAs suspension was diluted to multiple concentrations $(25,50$, or $100 \mu \mathrm{g} / \mathrm{mL})$. The suspension $(2 \mathrm{~mL})$ of different concentrations placed in quartz cuvette was irradiated with an $808 \mathrm{~nm}$ laser at different power densities $\left(2 \mathrm{~W} / \mathrm{cm}^{2}, 1 \mathrm{~W} / \mathrm{cm}^{2}\right.$ and $\left.0.5 \mathrm{~W} / \mathrm{cm}^{2}\right)$ for $10 \mathrm{~min}$. A thermocouple was immersed in the suspension and the temperature was measured every $30 \mathrm{~s}$. To assess the photothermal stability, Au- 80 CNAs $(100 \mu \mathrm{g} / \mathrm{mL})$ were irradiated for twice with about $1 \mathrm{~h}$ interval, and then we got the temperature elevation curves. The absorption spectra and the TEM images were also acquired for comparison.

\section{Cell culture}

Hep G2 cell lines were purchased from Cell Bank of Chinese Academy of Sciences (Shanghai, China). Hep G2 cells were cultured in Dulbecco's Modified Eagle's Medium (DMEM medium with high glucose, 
4.0 mM L-glutamine and $110 \mathrm{mg} / \mathrm{L}$ Sodium Pyruvate) supplemented with $10 \%$ fetal bovine serum (FBS, from Hyclone) and antibiotics $(100 \mu \mathrm{g} / \mathrm{mL}$ streptomycin, $100 \mathrm{U} / \mathrm{mL}$ penicillin and $0.25 \mu \mathrm{g} / \mathrm{mL}$ amphoterincin $\mathrm{B}$, from Hyclone) at $37^{\circ} \mathrm{C}$ in the humidified atmosphere with $5 \% \mathrm{CO}_{2}$.

\section{Cytotoxicity assay}

The cytotoxicity of the Au-80 CNAs nanoparticles was tested by 3-(4, 5-dimethylthiazol-2y1)-2,5-diphenyltetrazolium bromide (MTT) method. Hep G2 cells were seeded onto a 96-well plate with a density of $5 \times 10^{3}$ cells per well in DMEM, and incubated in the atmosphere of $5 \% \mathrm{CO}_{2}$ at $37{ }^{\circ} \mathrm{C}$ for $24 \mathrm{~h}$. The cells were then incubated with Au- 80 CNAs nanoparticles in DMEM culture medium at various concentrations for another $24 \mathrm{~h}$. Subsequently, the culture medium was removed, each well was added with $100 \mu \mathrm{L}$ new culture medium containing MTT $(0.5$ $\mathrm{mg} / \mathrm{mL}$ ) and the cells were incubated for another $4 \mathrm{~h}$ at $37^{\circ} \mathrm{C}$. Then the medium was removed and each well was added $200 \mu \mathrm{L}$ DMSO. The $\mathrm{OD}_{492}$ values (Abs.) of each wells were measured by a MultiSkan FC microplate reader immediately. Cell viability was calculated from $\mathrm{OD}_{492}$ value of experimental group by subtracting that of blank group.

\section{In vitro photothermal performance}

To assess the photothermal effect on cells, Hep G2 cells were seeded onto a 96-well plate at a density of $1 \times 10^{4}$ cells per well and were allowed to incubated for $24 \mathrm{~h}$. Then, the wells were divided into four groups. The three control groups included the blank, the Au-80 CNAs only and the laser irradiation only. The cells of the experiment group were incubated with $100 \mu \mathrm{L}$ fresh medium containing $100 \mu \mathrm{g} / \mathrm{mL}$ $\mathrm{Au}-80 \mathrm{CNAs}$ for $1 \mathrm{~h}$, and then irradiated on each well with an $808 \mathrm{~nm}$ laser at a power density of $2 \mathrm{~W} / \mathrm{cm}^{2}$ for $5 \mathrm{~min}$. The well was fully covered with laser spot. Then the cells of all groups were co-stained with both acridine orange (AO) and propidium iodide (PI). After rinsing with PBS three times, live and dead cells were imaged using Axio Observer. The cells could also be seeded in the $3.5 \mathrm{~cm}$ culture dish, incubated with Au-80 CNAs and partly covered with laser spot. After co-stained, a boundary between green and red could be obtained.

\section{In vivo photothermal performance}

Female Kunming mice were obtained from Laboratory Animal Center of Xiamen University and operated in compliance with the guideline for the care and use of Laboratory Animal Center of Xiamen University, China. To induce a solid tumor, S180 cells $\left(5 \times 10^{6}\right.$ in $\left.100 \mu \mathrm{L} \mathrm{PBS}\right)$ were injected subcutaneously into the right rear flank areas of the mice. The mice were used when the tumor grew to $\sim 5 \mathrm{~mm}$ in diameter. The S180 tumor-bearing mice were separated into four groups (five mice per group). For the experiment group (Au-80 CNAs + laser), S180 tumor-bearing mice were intratumorally injected with $120 \mu \mathrm{L}$ of 200 $\mu \mathrm{g} / \mathrm{mL}$ Au- $80 \mathrm{CNAs}$ and irradiated with the $808 \mathrm{~nm}$ laser at $1 \mathrm{~W} / \mathrm{cm}^{2}$ for $5 \mathrm{~min}$. The other three groups of mice were used as controls: no treatment (blank); irradiated with $808 \mathrm{~nm}$ laser at $1 \mathrm{~W} / \mathrm{cm}^{2}$ for $5 \mathrm{~min}$ but without injection of Au- 80 CNAs (laser only); intratumorally injected with $120 \mu \mathrm{L}$ of $200 \mu \mathrm{g} / \mathrm{mL}$ Au-80 CNAs but without laser irradiation (Au-80 CNAs only). The laser spot was adjusted to cover the entire region of the tumor. Then the sizes of tumors were measured by a caliper every other day and the tumor volume was calculated according to equation: Tumor volume $=($ tumor length $) \times(\text { tumor width })^{2} / 2$. Relative tumor volumes were calculated as $\mathrm{V} / \mathrm{V}_{0}(\mathrm{~V}$ was the tumor volume calculated after treatment, while $\mathrm{V}_{0}$ was the initiated tumor volume before treatment). The photographs were also taken by the camera to record the change of the tumors.

\section{In vivo photoacoustic imaging}

The Imaging System was equipped with a tunable Nd:YAG laser pumped OPO of a pulse width of 7 $\mathrm{ns}$, a repetition rate of $20 \mathrm{~Hz}$. The maximum energy density of the laser was about $20 \mathrm{~mJ}$ per pulse, which is below the ANSI limitation for laser skin exposure. The imaging information was acquired using 128-element unfocused ultrasound transducers of 5 $\mathrm{MHz}$ center frequency and $3 \mathrm{~mm}$ diameter. The S180 tumor-bearing mice were anesthetized using chloral hydrate. Photoacoustic information of tumor areas before and after intratumoral injection of Au-80 CNAs $(25 \mu \mathrm{g} / \mathrm{mL}, 50 \mu \mathrm{L})$ in mice was acquired under $808 \mathrm{~nm}$ excitation.

\section{Result and Discussion}

\section{Synthesis of Au CNAs with controllable sizes and tunable optical properties}

We prepared $\mathrm{Au}$ CNAs via a facile in situ reaction using $\mathrm{Cu}_{2} \mathrm{O}$ nanocubes as sacrificial templates. Firstly, we synthesized monodisperse $\mathrm{Cu}_{2} \mathrm{O}$ nanocubes by reducing copper (II) sulfate with ascorbic acid in the presence of mPEG-NH $\mathrm{N}_{2}$ at room temperature [40]. Then we employed the as-prepared $\mathrm{Cu}_{2} \mathrm{O}$ nanocubes as sacrificial templates to synthesize $\mathrm{Au} \mathrm{CNAs}$ according to the following redox reaction [41]:

$$
\begin{gathered}
3 \mathrm{Cu}_{2} \mathrm{O}+2 \mathrm{AuCl}_{4}^{-}+6 \mathrm{H}^{+}= \\
6 \mathrm{Cu}^{2+}+2 \mathrm{Au}+3 \mathrm{H}_{2} \mathrm{O}+8 \mathrm{Cl}^{-}
\end{gathered}
$$

After addition, the $\mathrm{AuCl}_{4}{ }^{-}$can be immediately 
reduced by $\mathrm{Cu}_{2} \mathrm{O}$ at room temperature since the standard reduction potential of $\mathrm{AuCl}_{4}^{-} / \mathrm{Au}(0.99 \mathrm{~V}$ vs SHE) is much higher than that of $\mathrm{Cu}^{2+} / \mathrm{Cu}_{2} \mathrm{O}(0.203 \mathrm{~V}$ vs SHE). Based on this stoichiometric relationship, $\mathrm{Cu}_{2} \mathrm{O}$ nanocubes can completely be converted into soluble $\mathrm{Cu}^{2+}$ ions, thus leaving behind the pure $\mathrm{Au}$ CNAs products.

By varying the amounts of mPEG-NH${ }_{2}$, we can synthesize $\mathrm{Cu}_{2} \mathrm{O}$ nanocubes with different sizes in a wide range from 70 to $700 \mathrm{~nm}$ such as the edge-length of $\sim 70, \sim 120$, and $\sim 170 \mathrm{~nm}$ (denoted as $\mathrm{Cu}_{2} \mathrm{O}-70$, $\mathrm{Cu}_{2} \mathrm{O}-120$, and $\mathrm{Cu}_{2} \mathrm{O}-170$, respectively). Using $\mathrm{Cu}_{2} \mathrm{O}$ nanocubes with different sizes as templates, we can produce $\mathrm{Au} \mathrm{CNAs}$ with the size ranging from 80 to $750 \mathrm{~nm}$ (Figure 1 and Supplementary Material: Figure $\mathrm{S1}$ ). For example, using $\mathrm{Cu}_{2} \mathrm{O}-70$ as a template, we made $\mathrm{Au} \mathrm{CNAs}$ with edge-length of $80 \mathrm{~nm}$. The scanning electron microscopy (SEM) images showed that the as-prepared $70 \mathrm{~nm} \mathrm{Cu}_{2} \mathrm{O}$ nanocubes had smooth surface. With increasing the amount of $\mathrm{HAuCl}_{4}$, the smooth $\mathrm{Cu}_{2} \mathrm{O}$ nanocubes gradually turned into the rough $\mathrm{Au}$ CNAs (Supplementary Material: Figure S2). Moreover, we can tune the optical properties of $\mathrm{Au}$ CNAs by adding different amount of $\mathrm{HAuCl}_{4}$ precursor. The pure $\mathrm{Cu}_{2} \mathrm{O}$ nanocubes solution exhibited no surface plasmon resonance (SPR) peaks in the range of $500-1200 \mathrm{~nm}$, while a new absorption peak appeared at around 600 $\mathrm{nm}$ and gradually shifted to $\sim 805 \mathrm{~nm}$ with increasing amount of $\mathrm{HAuCl}_{4}$ (Figure 2). Gold nanocrystals normally show a very intense color owing to SPR scattering, which is highly dependent on the particle size and shape [32, 42]. As the number of $\mathrm{Au}$ nanograins in $\mathrm{Au} \mathrm{CNAs}$ increases with the addition of $\mathrm{HAuCl}_{4}$ precursor, the interparticle distance between $\mathrm{Au}$ nanograins decreases, which results in the red shift of absorption peak [43].
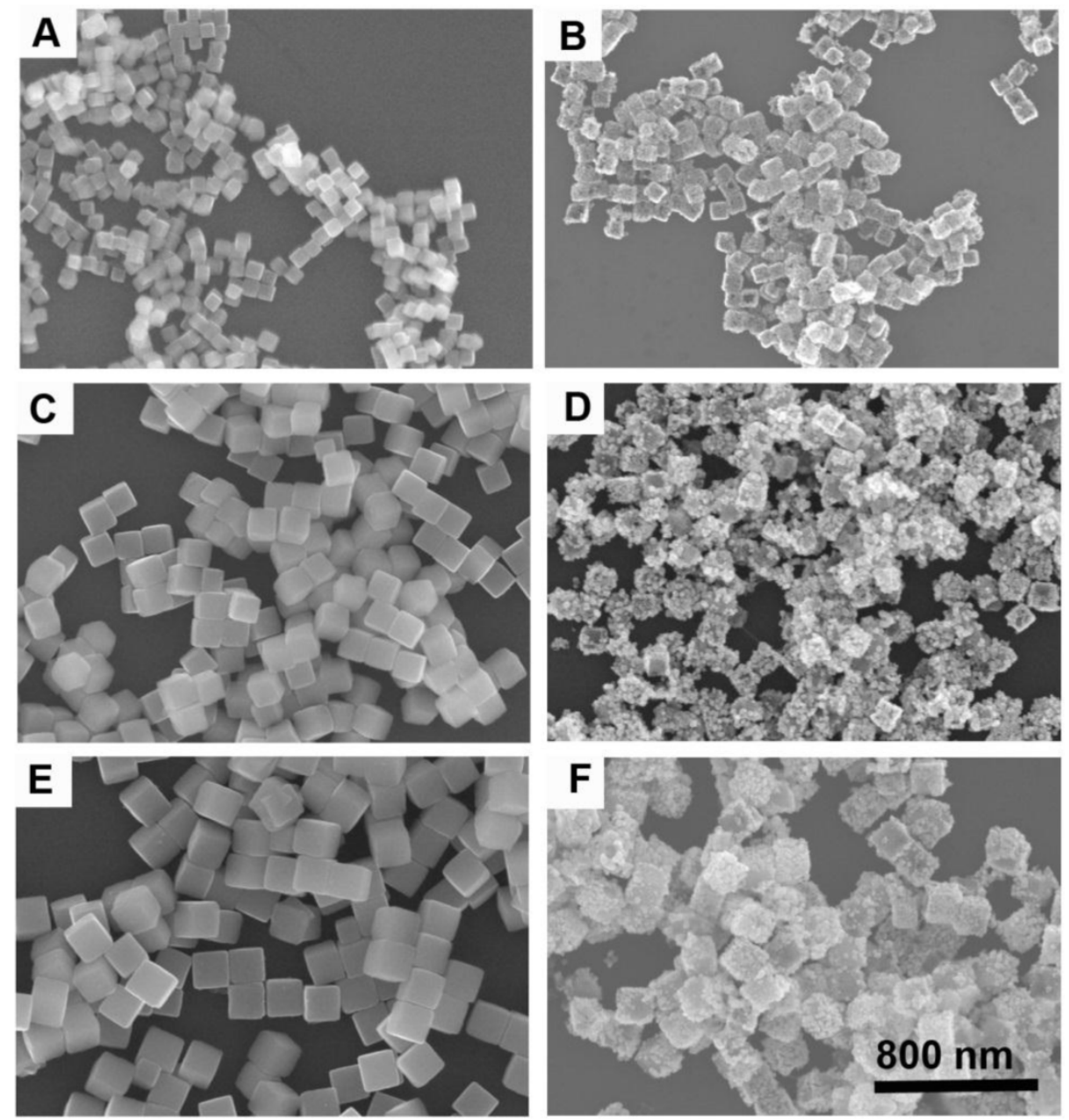

Figure I. SEM images of $\mathrm{Cu}_{2} \mathrm{O}-70$ (A), $\mathrm{Cu}_{2} \mathrm{O}-120$ (C), and $\mathrm{Cu}_{2} \mathrm{O}-170$ (E) as templates and the corresponding Au-80 CNAs (B), Au- I35 CNAs (D), and Au-195 CNAs (F). All images share the same scar bar. 


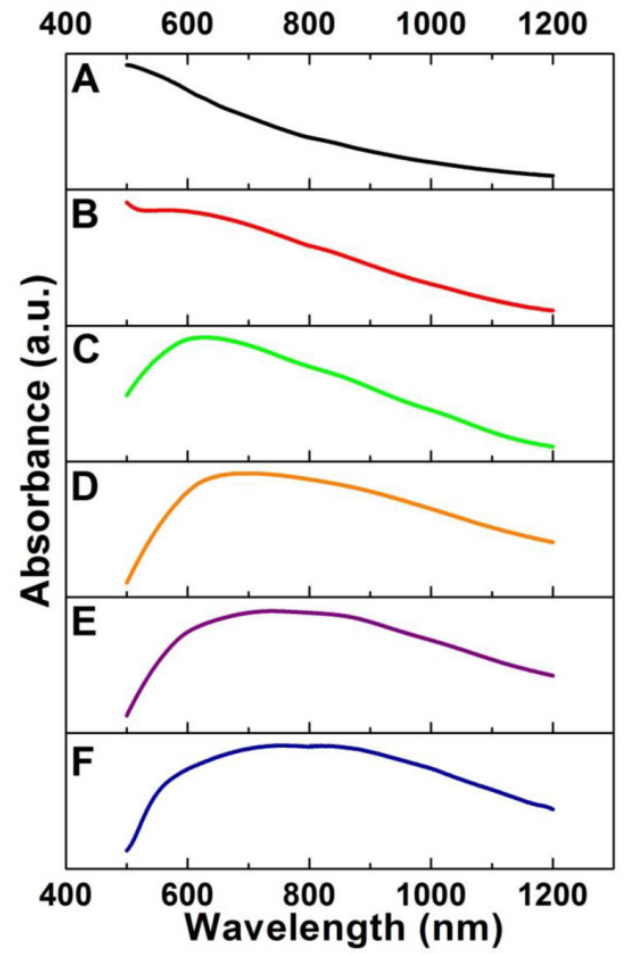

Figure 2. Absorption spectra of $\mathrm{Cu}_{2} \mathrm{O}-70$ nanocubes $(\mathrm{A})$ and $\mathrm{Au}-80 \mathrm{CNAs}$ with the tunable absorption peaks $\sim 560 \mathrm{~nm}(\mathrm{~B}), \sim 625 \mathrm{~nm}$ (C), $\sim 695 \mathrm{~nm}$ (D), $\sim 750 \mathrm{~nm}(\mathrm{E})$, and $\sim 805 \mathrm{~nm}(\mathrm{~F})$, respectively, by varying the amount of $\mathrm{HAuCl}_{4}$ precursor.

\section{Characterization of $\mathrm{Cu}_{2} \mathrm{O}-70$ nanocubes and Au-80 CNAs}

Because the nanoparticles with sizes range from 30 to $200 \mathrm{~nm}$ have long circulation time by reducing the uptake of the mononuclear phagocyte system (MPS) [44, 45], we choose $80 \mathrm{~nm}$ Au CNAs with the absorption peak at $\sim 805 \mathrm{~nm}$ for further exploration. The transmission electron microscopy (TEM) images (Figure $3 \mathrm{~A}$ ) revealed that the as-prepared $\mathrm{Cu}_{2} \mathrm{O}$ nanocubes exhibited a well-defined cubic shape with the average edge-lengths of about $70 \mathrm{~nm}$ and narrow size distribution (Supplementary Material: Figure S3A). The selected area electron diffraction (SAED) and the X-ray diffraction (XRD) patterns indicated that the $\mathrm{Cu}_{2} \mathrm{O}$ nanocubes were single crystal with cubic structure (JCPDS card no. 01-077-0199) (Figure $3 C)$. After the thoroughly template-sacrificing process, we made the as-synthesized Au CNAs composed of small Au nanograins with an average length of $\sim 80 \mathrm{~nm}$ (denoted as Au-80 CNAs). It is worthy note of that the contrast of the center (grey) of Au- 80 CNAs is lighter than its edges (dark), indicating the hollow interiors structure of $\mathrm{Au} \mathrm{CNAs}$ and implying that it may exhibit the similar optical properties to $\mathrm{Au}$ nanocages (Figure 3B). The corresponding SAED pattern of $\mathrm{Au} C \mathrm{CNAs}$ displayed an interplanar spacing originating from the face centered cubic (fcc) phase of $\mathrm{Au}$, indicating the polycrystalline feature of as-prepared Au-80 CNAs. The XRD pattern of Au-80 CNAs indicated a pure cubic phase of Au (JCPDS card no. 00-004-0784) without observable diffraction peaks of copper impurities (Figure 3D), which was further confirmed by the inductively coupled plasma atomic emission spectroscopy (ICP-AES) and energy dispersive spectrometer (EDS) measurements (Supplementary Material: Figure S4) of the Au- 80 CNAs samples. These results suggested that the $\mathrm{Cu}_{2} \mathrm{O}$ nanocubes were completely converted into soluble $\mathrm{Cu}^{2+}$ species and easily removed by a simple precipitation process, which is significantly important to the biomedical applications of Au-80 CNAs. The dynamics light scatter (DLS) analysis showed that the hydrodynamic diameter (HD) of Au-80 CNAs was $155 \mathrm{~nm}$ (Supplementary Material: Figure S5). The Au-80 CNAs with different concentrations exhibited broad and strong resonance absorption in the near-infrared (NIR) region. To evaluate the NIR photoabsorption capability, we calculated the molar extinction coefficient of Au- 80 CNAs to be about $2.19 \times 10^{10} \mathrm{M}^{-1} \mathrm{~cm}^{-1}$ at $808 \mathrm{~nm}$ (see Supporting Information for details). The molar extinction coefficient value is higher than those of reported Au nanorods in NIR region [46, 47], indicating the potential of Au- 80 CNAs to efficiently convert NIR light into heat. The absorbance intensity at $808 \mathrm{~nm}$ revealed a linear relationship as a function of concentration in accordance with Beer-Lambert's absorption law, which further indicated favorable dispersibility of Au-80 CNAs in aqueous solution (Supplementary Material: Figure S6).

\section{Photothermal conversion and stability of Au-80 CNAs in vitro}

The strong absorption in the NIR region and excellent water-solubility make it possible to use Au- 80 CNAs as photothermal conversion agents. To verify the potential of using Au- 80 CNAs as a PTT agent, Au-80 CNAs solutions with different concentrations were exposed to an $808 \mathrm{~nm}$ NIR laser at different power densities. The heating effect of Au- 80 CNAs aqueous solution increased with the enhanced concentrations and laser power density, indicating that the temperature elevation was highly dependent on the concentration and laser power density (Figure 4). For example, we observed that the irradiation of Au-80 CNAs aqueous solution even at the concentration of $25 \mu \mathrm{g} / \mathrm{mL}$ and the laser power density of 0.5 $\mathrm{W} / \mathrm{cm}^{2}$ for $10 \mathrm{~min}$ caused the temperature elevation of the solution as high as $\sim 10^{\circ} \mathrm{C}$. The temperature of Au-80 CNAs aqueous solution $(100 \mu \mathrm{g} / \mathrm{mL})$ increased by $\sim 38^{\circ} \mathrm{C}$ after irradiation of $808 \mathrm{~nm}$ laser at 2 $\mathrm{W} / \mathrm{cm}^{2}$ for $10 \mathrm{~min}$, which is much higher than that of pure water. These results confirmed that Au- 80 CNAs could rapidly convert the $808 \mathrm{~nm}$ laser energy into 
environmental heat. It is well known that the temperature maintaining at $42 \sim 45{ }^{\circ} \mathrm{C}$ for $30 \sim 60$ min could cause irreversible cellular damage. When the temperature rises to $50{ }^{\circ} \mathrm{C}$, protein denaturation occurs and the irreversible cellular damage happens promptly [48]. Therefore, the ability of Au-80 CNAs to induce temperature increase at low laser density suggests that Au-80 CNAs may be useful as photothermal mediators and cause irreversible damage to cancer cells and/or tissues.

To investigate the photothermal stability of $\mathrm{Au}-80 \mathrm{CNAs}$, we tested the photothermal conversion effect of the solution and examined the morphology change of Au CNAs after the irradiation. Interestingly, there was no significant discrepancy for the temperature elevation of the same $\mathrm{Au}-80 \mathrm{CNAs}$ solution between twice irradiation (Figure 5A), suggesting
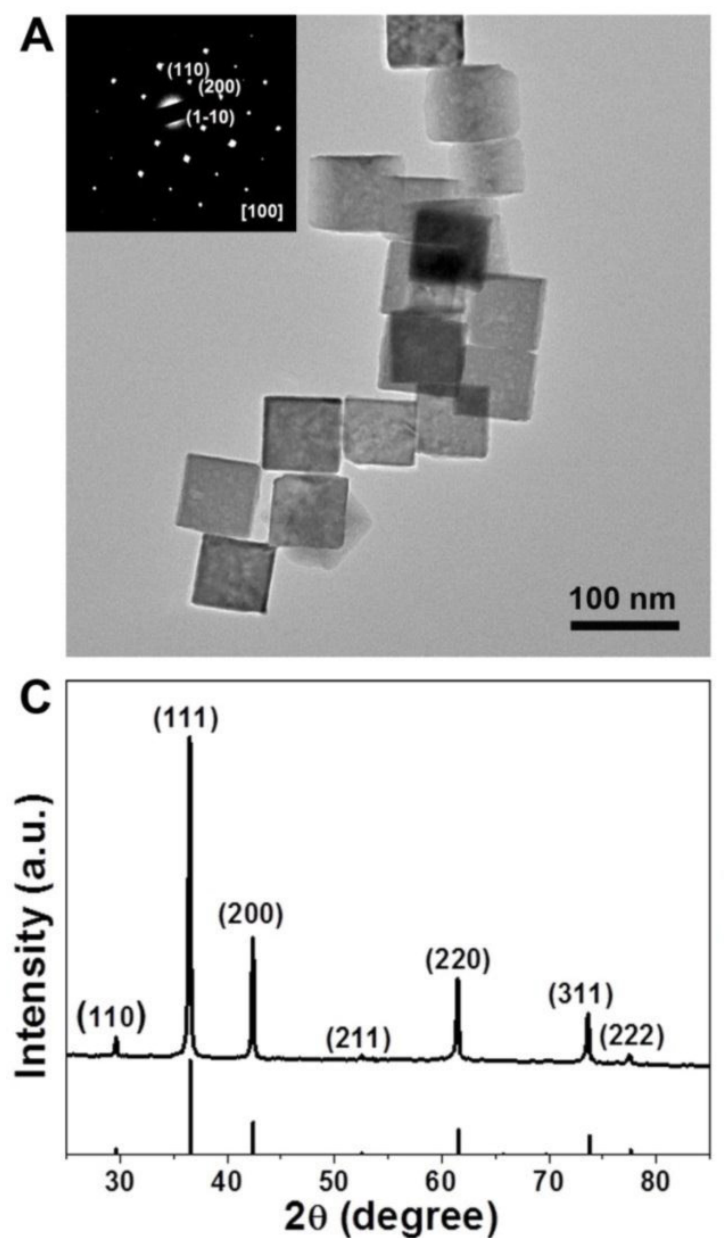

good photothermal stability of Au- 80 CNAs. The absorption spectra (Figure 5B) indicated that the Au- 80 CNAs in an aqueous solution before irradiation and after twice irradiation maintained nearly the same absorbance in NIR region. The photographs showed that $\mathrm{Au}-80 \mathrm{CNAs}$ aqueous solution was transparent and well-dispersed after twice irradiation. The TEM images also displayed that the morphology of Au-80 CNAs kept intact even after twice irradiation (Supplementary Material: Figure S7). By contrary, Au nanorods were prone to melt under the irradiation of an $808 \mathrm{~nm}$ laser according to the previous report [37]. These results imply that Au-80 CNAs with good stability and high photothermal effect can be used as promising exogenous photothermal agents for in vitro and in vivo applications.
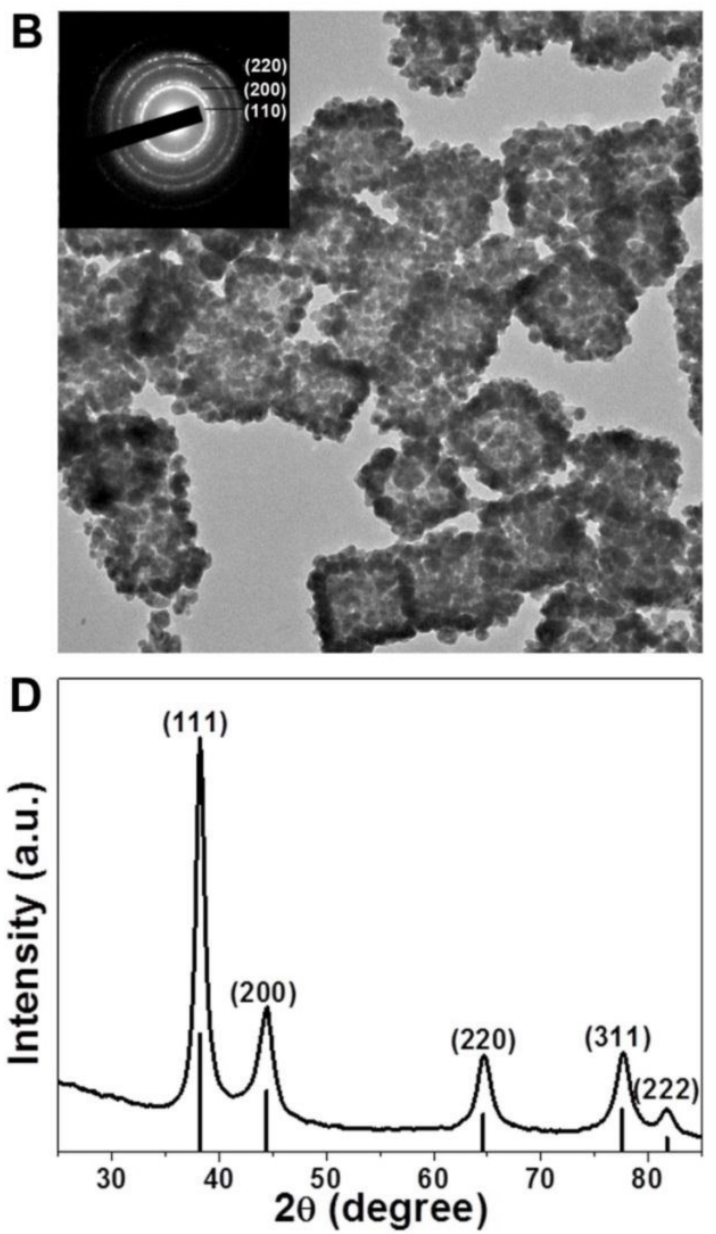

Figure 3. Representative TEM images of $\mathrm{Cu}_{2} \mathrm{O}-70$ nanocubes $(\mathrm{A})$ and $\mathrm{Au}-80 \mathrm{CNAs}(\mathrm{B})$. The insets in $(\mathrm{A})$ and $(\mathrm{B})$ are the selected-area electronic diffraction (SAED) patterns of $\mathrm{Cu}_{2} \mathrm{O}-70$ nanocubes and $\mathrm{Au}-80 \mathrm{CNAs}$, respectively. The $\mathrm{X}$-ray diffraction patterns of $\mathrm{Cu}_{2} \mathrm{O}-70$ nanocubes (C) and Au-80 CNAs, respectively (D). 

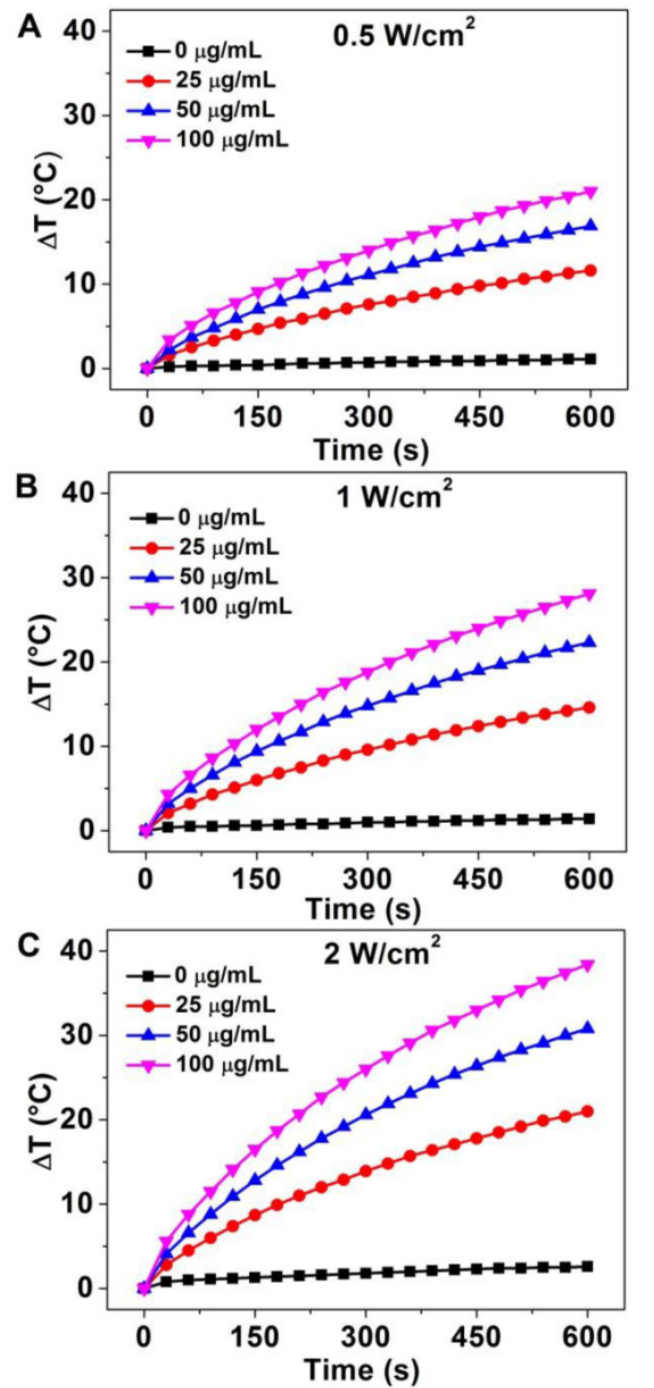

Figure 4. The temperature elevation curves of aqueous solution of Au- 80 CNAs with different concentration $(0,25,50,100 \mu \mathrm{g} / \mathrm{mL})$ as a function of irradiation time by $808 \mathrm{~nm}$ laser at different laser power density: (A) $0.5 \mathrm{~W} / \mathrm{cm}^{2}$, (B) $1 \mathrm{~W} / \mathrm{cm}^{2}$, and (C) 2 $\mathrm{W} / \mathrm{cm}^{2}$.

\section{In vitro cell assay}

We next assessed the suitability of Au- 80 CNAs as photothermal therapy agents at cellular level using 3-(4,5-dimethylthiazol-2-yl)-2,5-diphenyltetrazolium bromide (MTT) assay. After $24 \mathrm{~h}$ incubation of Hep G2 cells with the Au- 80 CNAs, no apparent cytotoxicity was found even at the concentration of Au- 80 CNAs as high as $200 \mu \mathrm{g} / \mathrm{mL}$, demonstrating the acceptable biocompatibility of Au-80 CNAs (Supplementary Material: Figure S8). The biocompatibility is closely related with the biological inertness of $\mathrm{Au}$ and the mPEG-NH$H_{2}$ coating $[49,50]$. To further investigate in vitro photothermal therapy effect of Au- 80 CNAs, Hep G2 cells were incubated with the Au-80 CNAs $(100 \mu \mathrm{g} / \mathrm{mL})$ and then exposed to an $808 \mathrm{~nm}$ NIR laser at $2 \mathrm{~W} / \mathrm{cm}^{2}$ for $5 \mathrm{~min}$. Three other groups including untreated, laser irradiation only treated, and Au- 80
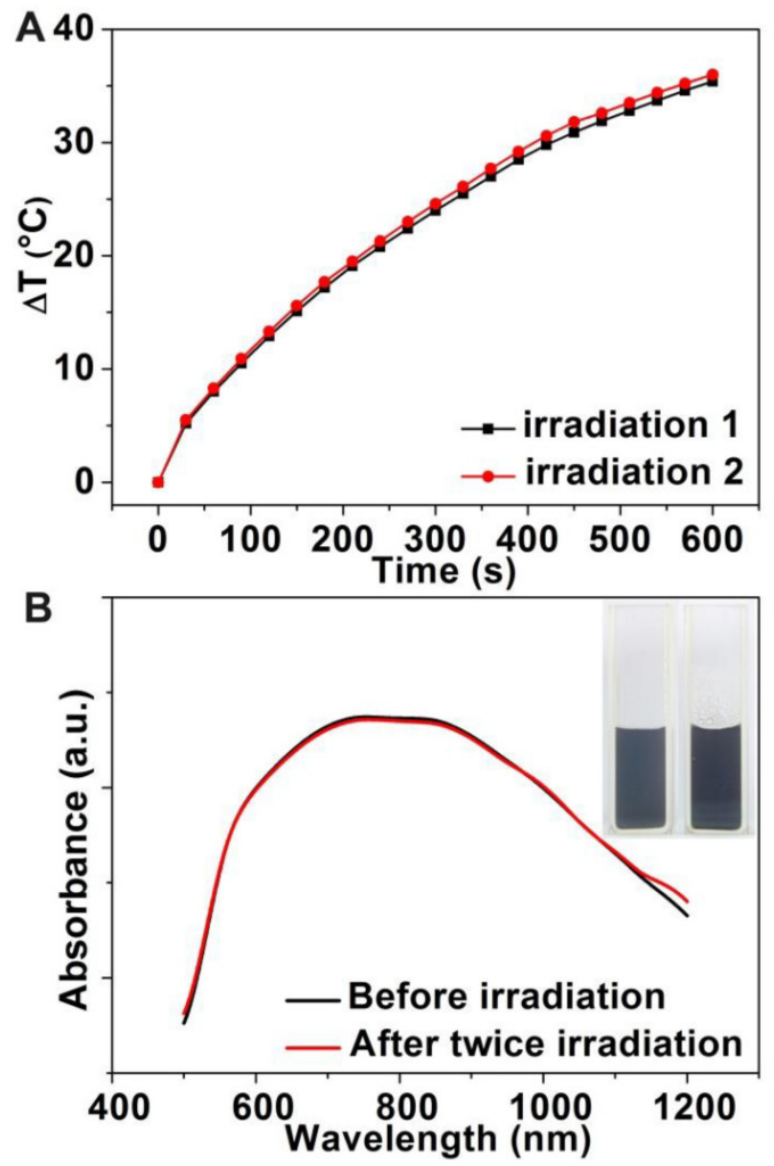

Figure 5. (A) The temperature elevation curves of the aqueous solution of $A u-80$ CNAs $(100 \mu \mathrm{g} / \mathrm{mL})$ for twice irradiation. (B) The absorption spectra of the Au- 80 CNAs aqueous solution before irradiation and after twice irradiation (The inset is the photograph of Au- $80 \mathrm{CNAs}$ aqueous solution in quartz cuvette before and after twice irradiation).
CNAs only treated cells were used as controls. After treatments, the cells were co-stained with acridine orange (AO) and propidium iodide (PI) to evaluate cell viability. AO can enter the live cells and bind to the DNA, emitting green fluorescence, while PI can only penetrate through the dead cells membrane and stain the DNA when the cell membrane is irreversibly damaged, emitting red fluorescence under excitation. The merged fluorescence images of three control groups all exhibited green fluorescence (Figure 6A-C), indicating the negligible cell destruction. The merged fluorescence images of laser and Au- 80 CNAs co-treated group exhibited red fluorescence, indicating almost all of the cells were dead (Figure 6D). It could be concluded that the death of Hep G2 cells was ascribed to the photothermal effects of Au- 80 CNAs instead of the cytotoxicity of the Au- $80 \mathrm{CNAs}$ or the 
single irradiation of $808 \mathrm{~nm}$ NIR laser. The cells partly covered with laser spot showed a boundary between green and red fluorescence in accordance with the laser spot, further confirming that Au-80 CNAs could effectively kill the cancer cells only exposure to both NIR irradiation and Au-80 CNAs (Figure 6E, F).
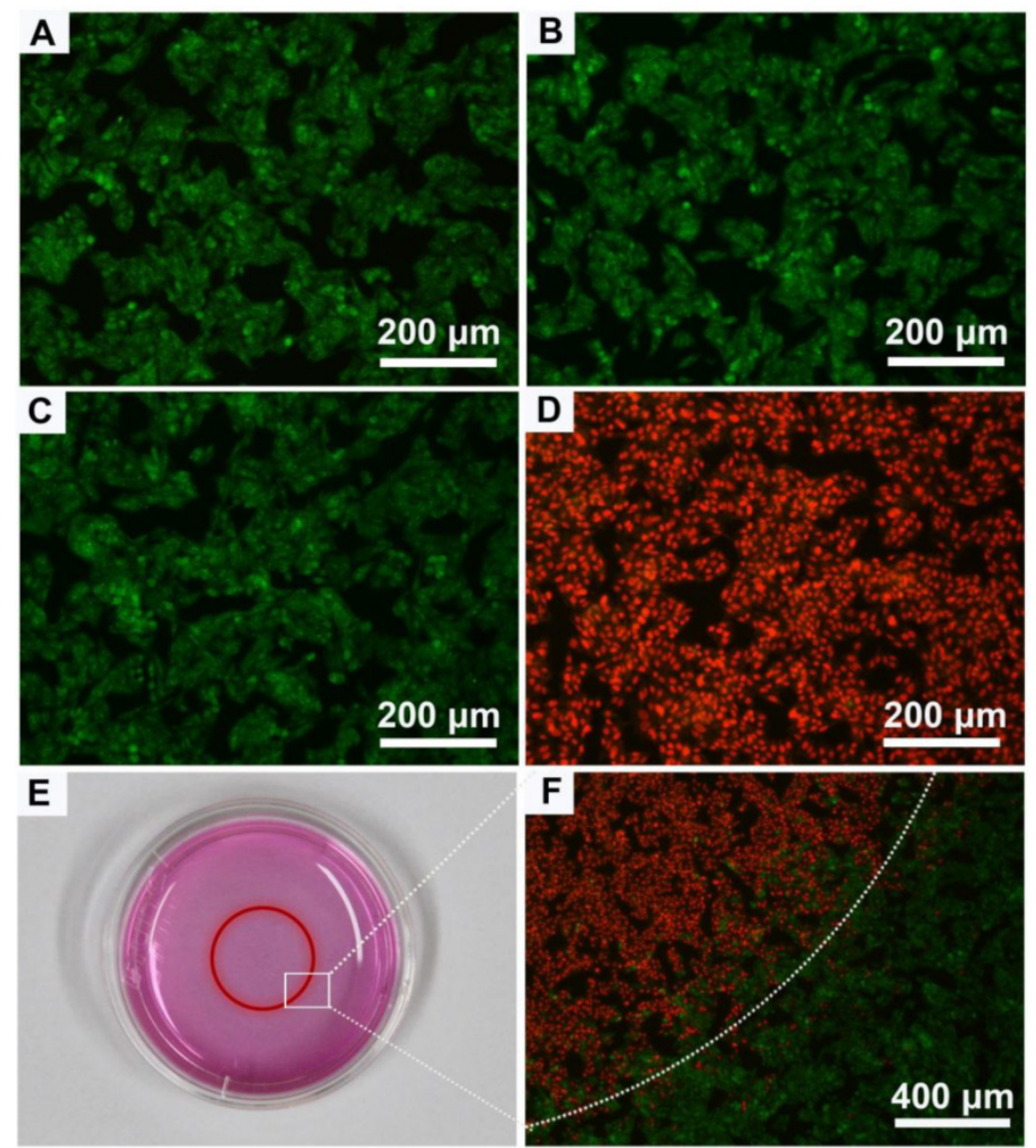

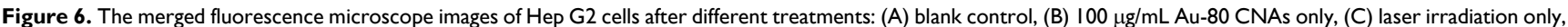
(D) combination of $100 \mu \mathrm{g} / \mathrm{mL}$ Au- $80 \mathrm{CNAs}$ and laser irradiation. (E) The photograph of cell culture dish of Hep $\mathrm{G} 2$ cells. The red circle shows the laser spot area. (F) The merged fluorescence image of Hep G2 cells after treatment with $100 \mu \mathrm{g} / \mathrm{mL}$ Au CNAs and laser irradiation in $3.5 \mathrm{~cm}$ dish. The cells are all co-stained by acridine orange (live: green) and propidium iodide (dead: red). Laser, $808 \mathrm{~nm}, 2 \mathrm{~W} / \mathrm{cm}^{2}$ for $5 \mathrm{~min}$.

\section{In vivo photothermal therapy using Au-80 CNAs}

We further investigated the in vivo therapeutic effect of Au-80 CNAs. We used the Kunming mice with xenografted S180 tumors as models, and randomly divided mice into four groups $(n=5$ for each group) as follows: mice untreated (blank), mice irradiated with the laser for $5 \mathrm{~min}$ (laser only), mice intratumorally injected with Au- 80 CNAs but without laser irradiation (Au-80 CNAs only), and mice intratumorally injected with Au-80 CNAs and with laser irradiation for $5 \mathrm{~min}$ (Au-80 CNAs + laser). To verify the in vivo photothermal conversion effect generated by Au- 80 CNAs, we used an infrared (IR) thermal mapping apparatus to record the temperature change in the tumor area. IR thermographic images of mice showed that the temperature in tumor site could rapidly reach to $57.5^{\circ} \mathrm{C}$ in the presence of Au- 80 CNAs upon the NIR laser illumination within $5 \mathrm{~min}$.
In comparison, the maximum temperature of the tumor surface in the laser only group was only about $38.5^{\circ} \mathrm{C}$ under the same irradiation condition, demonstrating that Au-80 CNAs played a key role in the generation of heat (Figure 7A, B). The temperature exceeding $50{ }^{\circ} \mathrm{C}$ would cause an irreversible damage to the cells and tissues. The subsequent hematoxylin and eosin (H\&E) staining of tumor tissues indicated that there was no obvious destruction in the tumors after single treatment of either the laser or Au- 80 CNAs; however, tumors exhibited the cells karyolysis and cytoplasmic acidophilia after both Au-80 CNAs and laser treatments (Supplementary Material: Figure S9). This result confirmed that only Au- 80 CNAs under irradiation could generate enough heat and damage the cancer cells and tissues irreversibly [51]. To verify the photothermal theraputic efficacy of Au- 80 CNAs, we monitored mice tumor growth rates and the mice survival rates. The tumor tissues after single treatment of injected with Au- 80 CNAs or irra- 
diated with NIR laser all continuously grew and showed no significant difference of tumor growth compared to the untreated control group mice. The rapid growth led to the necrosis within tumors, and finally caused the death of mice. However, the mice after treatment of both Au- 80 CNAs and $808 \mathrm{~nm}$ laser irradiation showed seriously empyrosis in tumor areas and resulted in a significant suppression of tumor growth. The black burning scab detached from the skin after 14 days, and the mice completely recovered (Figure 7C, D and Supplementary Material: Figure S10). The inhibition of tumor growth in mice treated with the combination of Au- 80 CNAs and NIR laser lead to a significantly survival superiority. The recovered mice survived without tumor recurrence over 60 days. However, the tumors in other 3 groups grew rapidly and lead to the death of mice in no more than 25 days (Figure 7E). These results confirm that Au- 80 CNAs would be efficient PTT agents which cause cancer cells death and tumor tissues injury through the conversion of the strongly absorbed NIR light to sufficient thermal energy.

\section{In vivo photoacoustic imaging by Au-80 CNAs}

PAI can reveal a wide variety of endogenous absorbers in biological systems, such as DNA/RNA, hemoglobin, melanin. To visualize and distinguish the tumor tissues from normal tissues by PAI, an exogenous contrast agent will be required [28-30]. Apart from the excellent in vitro photothermal performance and favorable in vivo therapeutic effect, Au-80 CNAs with strong NIR absorption also serve as an excellent candidate for PAI contrast enhancement. We tested the contrast ability in mice tumors after intratumoral injection of $50 \mu \mathrm{L}$ of Au- 80 CNAs $(25 \mu \mathrm{g} / \mathrm{mL})$. The photoacoustic signal in the region of interest (ROI) increased about 4-fold compared with that of the same region before injection, suggesting the feasibility of Au-80 CNAs for PAI contrast enhancement and diagnostic applications (Figure 8A, B). Au-80 CNAs, one nano-entity with the excellent photothermal theraputic effect and the enhanced photoacoustic contrast ability, can provide an important and promising platform for cancer theranostics [52-54].
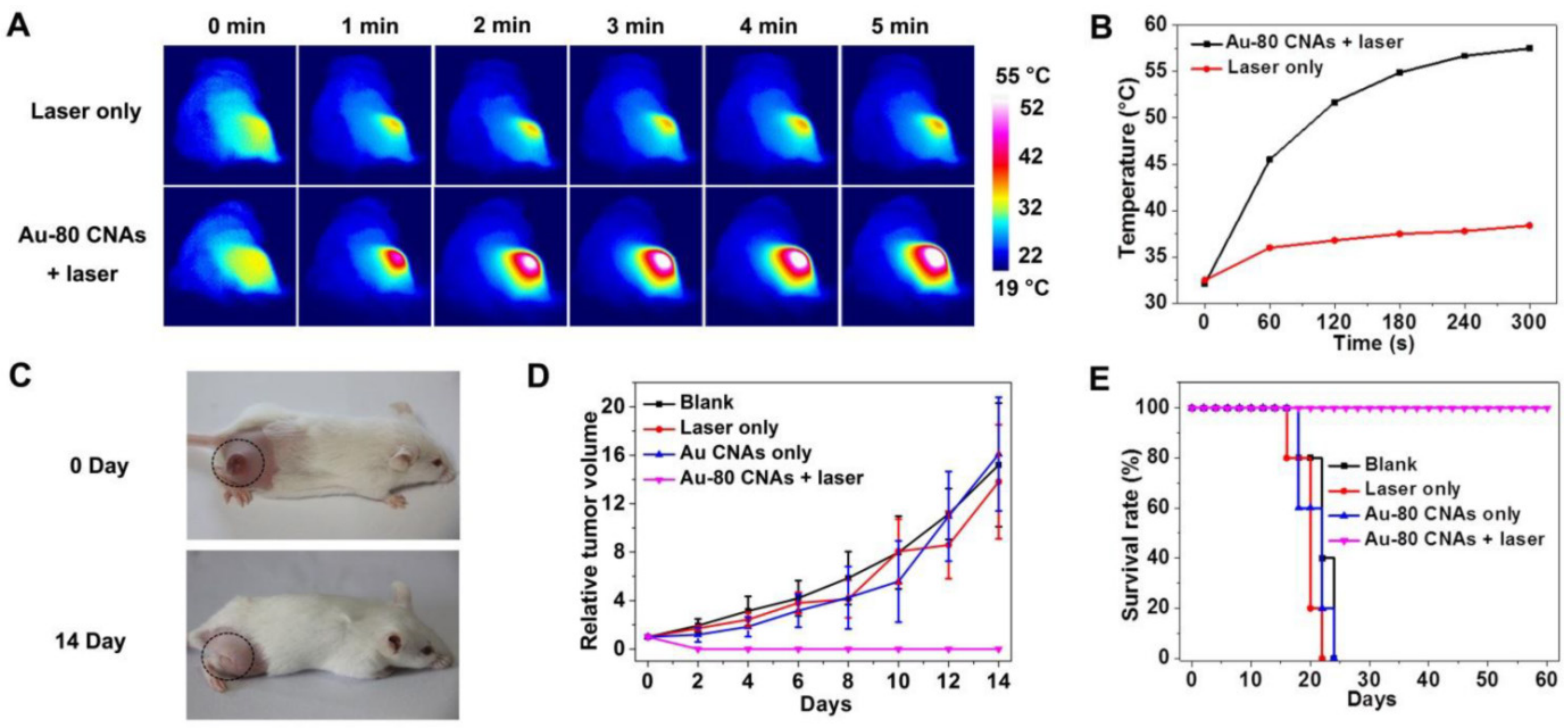

D

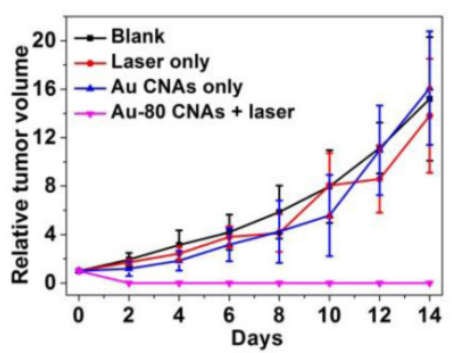

E

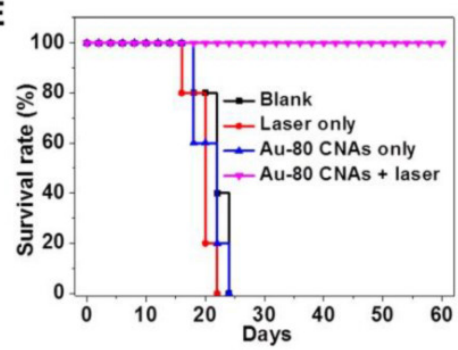

Figure 7. (A) IR thermographs at the time points of $0,1,2,3,4,5$ min of the mice tumor sites without (upper row) and with (lower row) intratumoral injection of Au-80 CNAs with irradiation by $808 \mathrm{~nm}$ laser at I W/cm². (B) Temperature change of the mice tumor sites as the function of irradiation time. (C) The digital photographs of SI 80 tumor-bearing mice taken at 0 day before treatments and 14 days after treatments of Au- $80 \mathrm{CNAs}+$ laser (intratumorally injected I20 $\mu \mathrm{L}$ of $200 \mu \mathrm{g} / \mathrm{mL} \mathrm{Au-80} \mathrm{CNAs} \mathrm{and} \mathrm{then}$ immediately exposed to $808 \mathrm{~nm}$ laser at I W/cm² for $5 \mathrm{~min}$ ). (D) Relative tumor volume change of the SI80 tumor-bearing mice of different groups after treatments. (E) The survival rate curves of $\mathrm{SI} 80$ tumor-bearing mice of different groups after treatments.
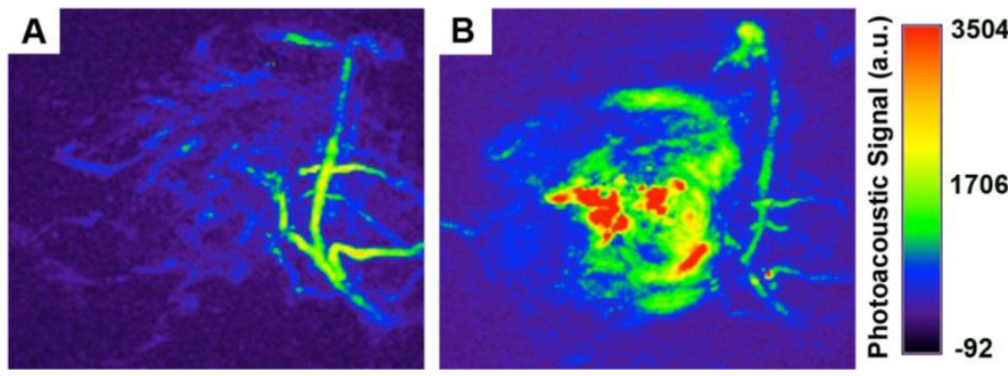

Figure 8. Representative in vivo photoacoustic images of tumor areas before (A) and after (B) injection of Au- $80 \mathrm{CNAs}(25 \mu \mathrm{g} / \mathrm{mL}, 50 \mu \mathrm{L})$ in mice tumors. Laser: $808 \mathrm{~nm}$. 


\section{Conclusion}

In summary, we have demonstrated that a novel $\mathrm{Au}$ cubic nano-aggregate structure could serve as a potential theranostic agent. The as-synthesized Au- 80 CNAs with intense NIR absorption exhibit good photo-stability, excellent photothermal effect, and high biocompatibility, which allow Au- 80 CNAs (only one entity) to act as an in vivo exogenous agent for both PAI and PTT applications. The synthesis of size-controllable $\mathrm{Au} \mathrm{CNAs}$ is facile, cost-effective, highly reproducible, and amenable to scale up. We thus believe that the powerful and stable dual-functional metallic $\mathrm{Au}$ CNAs hold a great promise for biomedical applications, particularly cancer imaging and therapy.

\section{Supplementary Material}

Table S1, Fig.S1 - Fig.S10.

http://www.thno.org/v04p0534s1.pdf

\section{Acknowledgment}

This work was supported by the National Key Basic Research Program of China (2013CB933901 and 2014CB744502), National Natural Science Foundation of China (21222106, 81370042, 81000662, and 81201805), Natural Science Foundation of Fujian (2013J06005 and 2013D014), Program for New Century Excellent Talents in University (NCET-10-0709), and Projects of Xiamen Science and Technology Program (3502Z20130030).

\section{Competing Interests}

The authors have declared that no competing interest exists.

\section{References}

1. Li Y, Somorjai GA. Nanoscale advances in catalysis and energy applications. Nano Lett. 2010;10:2289-95.

2. Zhou X, Xu W, Liu G, et al. Size-dependent catalytic activity and dynamics of gold nanoparticles at the single-molecule level. J Am Chem Soc. 2010;132:138-46.

3. Gudiksen MS, Lauhon LJ, Wang J, et al. Growth of nanowire superlattice structures for nanoscale photonics and electronics. Nature. 2002;415:617-20.

4. Li CZ, Liu Y, Luong JH. Impedance sensing of DNA binding drugs using gold substrates modified with gold nanoparticles. Anal Chem. 2005:77:478-85.

5. Cheng Y, A CS, Meyers JD, et al. Highly efficient drug delivery with gold nanoparticle vectors for in vivo photodynamic therapy of cancer. J Am Chem Soc. 2008;130:10643-7.

6. Ghosh P, Han G, De M, et al. Gold nanoparticles in delivery applications. ADV DRUG DELIVER REV. 2008;60:1307-15.

7. Dickerson EB, Dreaden EC, Huang $X$, et al. Gold nanorod assisted near-infrared plasmonic photothermal therapy (PPTT) of squamous cell carcinoma in mice. Cancer Lett. 2008;269:57-66.

8. Wang S, Huang P, Nie L, et al. Single continuous wave laser induced photodynamic/plasmonic photothermal therapy using photosensitizer-functionalized gold nanostars. Adv Mater. 2013;25:3055-61.

9. Cheong S, Ferguson P, Feindel KW, et al. Simple synthesis and functionalization of iron nanoparticles for magnetic resonance imaging. Angew Chem Int Ed. 2011:50:4206-9.

10. Chen H, Zhang X, Dai S, et al. Multifunctional gold nanostar conjugates for tumor imaging and combined photothermal and chemo-therapy. Theranostics. 2013;3:633-49.
11. Wang LV, Hu S. Photoacoustic tomography: in vivo imaging from organelles to organs. Science. 2012;335:1458-62.

12. Wang $\mathrm{X}$, Pang $\mathrm{Y}, \mathrm{Ku} \mathrm{G}$, et al. Noninvasive laser-induced photoacoustic tomography for structural and functional in vivo imaging of the brain. Nat Biotechnol. 2003;21:803-6.

13. Lal S, Clare SE, Halas NJ. Nanoshell-enabled photothermal cancer therapy: impending clinical impact. Accounts Chem Res. 2008:41:1842-51.

14. Zha Z, Yue X, Ren Q, et al. Uniform polypyrrole nanoparticles with high photothermal conversion efficiency for photothermal ablation of cancer cells. Adv Mater. 2013;25:777-82.

15. Gao J, Gu H, Xu B. Multifunctional magnetic nanoparticles: design, synthesis, and biomedical applications. Accounts Chem Res. 2009;42:1097-107.

16. Dreaden EC, El-Sayed MA. Detecting and destroying cancer cells in more than one way with noble metals and different confinement properties on the nanoscale. Accounts Chem Res. 2012;45:1854-65.

17. Bardhan R, Lal S, Joshi A, et al. Theranostic nanoshells: from probe design to imaging and treatment of cancer. Accounts Chem Res. 2011;44:936-46.

18. Xiao $\mathrm{Q}$, Zheng $\mathrm{X}, \mathrm{Bu} \mathrm{W}$, et al. A core/satellite multifunctional nanotheranostic for in vivo imaging and tumor eradication by radiation/photothermal synergistic therapy. J Am Chem Soc. 2013;135:13041-8.

19. Menon JU, Jadeja P, Tambe P, et al. Nanomaterials for photo-based diagnostic and therapeutic applications. Theranostics. 2013;3:152-66.

20. Jain PK, Huang X, El-Sayed IH, et al. Noble metals on the nanoscale: optical and photothermal properties and some applications in imaging, sensing, biology, and medicine. Accounts Chem Res. 2008;41:1578-86.

21. Dreaden EC, Alkilany AM, Huang X, et al. The golden age: gold nanoparticles for biomedicine. Chem Soc Rev. 2012;41:2740-79.

22. Wang X, Wang C, Cheng L, et al. Noble metal coated single-walled carbon nanotubes for applications in surface enhanced Raman scattering imaging and photothermal therapy. J Am Chem Soc. 2012;134:7414-22.

23. Hirsch LR, Stafford RJ, Bankson JA, et al. Nanoshell-mediated near-infrared thermal therapy of tumors under magnetic resonance guidance. Proc Natl Acad Sci. 2003;100:13549-54.

24. Huang X, El-Sayed IH, Qian W, et al. Cancer cell imaging and photothermal therapy in the near-infrared region by using gold nanorods. J Am Chem Soc. 2006;128:2115-20.

25. Chen J, Glaus C, Laforest R, et al. Gold nanocages as photothermal transducers for cancer treatment. Small. 2010;6:811-7.

26. Ye E, Win KY, Tan HR, et al. Plasmonic gold nanocrosses with multidirectional excitation and strong photothermal effect. J Am Chem Soc. 2011;133:8506-9.

27. Dong $\mathrm{W}, \mathrm{Li} \mathrm{Y}$, Niu $\mathrm{D}$, et al. Facile synthesis of monodisperse superparamagnetic Fe3O4 Core@hybrid@Au shell nanocomposite for bimodal imaging and photothermal therapy. Adv Mater. 2011;23:5392-7.

28. Kim C, Cho EC, Chen J, et al. In vivo molecular photoacoustic tomography of melanomas targeted by bioconjugated gold nanocages. Acs Nano. 2010;4:4559-64.

29. Wang Y, Xie X, Wang X, et al. Photoacoustic Tomography of a Nanoshell Contrast Agent in the in Vivo Rat Brain. Nano Lett. 2004;4:1689-92.

30. Jokerst JV, Thangaraj M, Kempen PJ, et al. Photoacoustic imaging of mesenchymal stem cells in living mice via silica-coated gold nanorods. Acs Nano. 2012;6:5920-30.

31. Zhang YS, Wang Y, Wang L, et al. Labeling human mesenchymal stem cells with gold nanocages for in vitro and in vivo tracking by two-photon microscopy and photoacoustic microscopy. Theranostics. 2013:3:532-43.

32. Hu M, Chen J, Li ZY, et al. Gold nanostructures: engineering their plasmonic properties for biomedical applications. Chem Soc Rev. 2006;35:1084-94

33. Xia Y, Li W, Cobley CM, et al. Gold nanocages: from synthesis to theranostic applications. Accounts Chem Res. 2011;44:914-24.

34. Jin Y. Multifunctional Compact Hybrid Au Nanoshells: A New Generation of Nanoplasmonic Probes for Biosensing, Imaging, and Controlled Release. Accounts Chem Res. 2013; doi: 10.1021/ar400086e.

35. Gad SC, Sharp KL, Montgomery C, et al. Evaluation of the toxicity of intravenous delivery of auroshell particles (gold-silica nanoshells). Int J Toxicol. 2012;31:584-94

36. Wang $\mathrm{Y}$, Black $\mathrm{KC}$, Luehmann $\mathrm{H}$, et al. Comparison study of gold nanohexapods, nanorods, and nanocages for photothermal cancer treatment. ACS Nano. 2013;7:2068-77.

37. Link S, Burda C, Mohamed MB, et al. Laser Photothermal Melting and Fragmentation of Gold Nanorods: Energy and Laser Pulse-Width Dependence. The Journal of Physical Chemistry A. 1999;103:1165-70.

38. Liu Y, Ai K, Liu J, et al. Dopamine-Melanin Colloidal Nanospheres: An Efficient Near-Infrared Photothermal Therapeutic Agent for In Vivo Cancer Therapy. Adv Mater. 2013;25:1353-9.

39. Skrabalak SE, Au L, Li X, et al. Facile synthesis of Ag nanocubes and $\mathrm{Au}$ nanocages. NAT PROTOC. 2007;2:2182-90.

40. Gou L, Murphy CJ. Controlling the size of $\mathrm{Cu}_{2} \mathrm{O}$ nanocubes from 200 to $25 \mathrm{~nm}$. J Mater Chem. 2004;14:735.

41. Liu XW. Selective growth of $\mathrm{Au}$ nanoparticles on (111) facets of $\mathrm{Cu}_{2} \mathrm{O}$ microcrystals with an enhanced electrocatalytic property. Langmuir. 2011;27:9100-4

42. Murphy CJ, Gole AM, Stone JW, et al. Gold Nanoparticles in Biology Beyond Toxicity to Cellular Imaging. Accounts Chem Res. 2008;41:1721-30. 
43. Elghanian R, Storhoff JJ, Mucic RC, et al. Selective colorimetric detection of polynucleotides based on the distance-dependent optical properties of gold nanoparticles. Science. 1997;277:1078-81.

44. Petros RA, DeSimone JM. Strategies in the design of nanoparticles for therapeutic applications. NAT REV DRUG DISCOV. 2010;9:615-27.

45. Albanese A, Tang PS, Chan WC. The effect of nanoparticle size, shape, and surface chemistry on biological systems. Annu Rev Biomed Eng. 2012;14:1-16.

46. Orendorff CJ, Murphy CJ. Quantitation of metal content in the silver-assisted growth of gold nanorods. J Phys Chem B. 2006;110:3990-4.

47. Liao H, Hafner JH. Gold Nanorod Bioconjugates. Chem Mater. 2005;17:4636-41.

48. Habash RW, Bansal R, Krewski D, et al. Thermal therapy, part 1: an introduction to thermal therapy. Crit Rev Biomed Eng. 2006;34:459-89.

49. Sperling RA, Rivera Gil P, Zhang F, et al. Biological applications of gold nanoparticles. Chem Soc Rev. 2008;37:1896-908.

50. Yu WW, Chang E, Falkner JC, et al. Forming biocompatible and nonaggregated nanocrystals in water using amphiphilic polymers. J Am Chem Soc. 2007;129:2871-9.

51. Zhou M, Zhang R, Huang M, et al. A Chelator-Free Multifunctional [64Cu]CuS Nanoparticle Platform for Simultaneous Micro-PET CT Imaging and Photothermal Ablation Therapy. J Am Chem Soc. 2010;132:15351-8.

52. Santra S, Kaittanis C, Santiesteban OJ, et al. Cell-specific, activatable, and theranostic prodrug for dual-targeted cancer imaging and therapy. J Am Chem Soc. 2011;133:16680-8.

53. Ke H, Wang J, Dai Z, et al. Gold-nanoshelled microcapsules: a theranostic agent for ultrasound contrast imaging and photothermal therapy. Angew Chem Int Ed. 2011;50:3017-21.

54. Zhang Z, Wang J, Chen C. Gold nanorods based platforms for light-mediated theranostics. Theranostics. 2013;3:223-38. 